\title{
A COMPARISON OF AFRICANIZED AND EUROPEAN DRONES : WEIGHTS, MUCUS GLAND AND SEMINAL VESICLE WEIGHTS, AND COUNTS OF SPERMATOZOA
}

Thomas E. RINDERER, Anita M. COLLINS and Daniel PESANTE

with the technical collaboration of Robert DANIEL, Vicki LANCASTER and James BAXTER

United States Department of Agriculture

Agriculture Research Service Bee Breeding \& Stock Center Laboratory

Box 82-B, Baton Rouge, LA 70820, USA

\section{SUMMARY}

Africanized drones weigh significantly less than European drones and produce significantly fewer spermatozoa. The weights of the seminal vesicles and the mucus glands of Africanized drones are similar to those of European drones.

\section{INTRODUCTION}

The Africanization of South and Central American honey bee (Apis mellifera L.) populations (MICHENER, 1975) has resulted in a wide variety of studies comparing Africanized and European honey bee stocks. In the main, most of these studies compare characteristics of worker bees.

More rarely, drones have been studied and compared. KERR and BUENo (1970) showed that queens and drones of both geographical types (1) engaged in a limited proportion $(\simeq 0.6)$ of positive assortive mating (like-to-like).

(1) The European honeybees in this study were from North America. Such bees have in their ancestry representatives of mixed subspecies. Africanized bees are descendants of $A$. $m$. scutellata bees imported from Africa and their hybrids with various subspecies previously imported into Brazil. Neither the European nor the Africanized bees can correctly be called race, subspecies, stock, or line representatives. We use the term «geographical type » to indicate that the bees we studied showed major characteristics typical of descriptions for temperately or tropically $(A . m$. scutellata) adapted bees. 
DiETZ (1979) reported that Africanized and European drones had different numbers of sensory receptors in differently shaped sensory depressions on antennal segments 11, 10 and 9. DALY and Hoelmer (1985) found taxonomically useful differences in the forewings of Africanized and European drones.

Recently, Rinderer et al. (1985 a) reported that adult Africanized drones parasitized European colonies and in doing so probably depressed the drone production of European colonies. This finding shows that Africanized drones are an important factor in the Africanization of European bee stocks. A thorough examination of the comparative reproductive potential of Africanized and European drones is desirable. This study is a contribution to that examination. It compares the weights, the weight of seminal vesicles and mucus glands, and spermatozoa counts of Africanized and European drones.

\section{MATERIAL AND METHODS}

All drones came from apiaries located near Sarare, Venezuela $\left(10^{\circ} \mathrm{N} 60^{\circ} \mathrm{W}\right)$ during the main nector-flow period of late November to early December.

For weights of drones, colonies were opened and young, apparently freshly emerged drones were collected from the combs. A group of eight to usually ten drones was collected from each of 34 Africanized and 25 European colonies, killed by freezing and weighed on an electronic balance. Average individual weights of drones were then calculated.

For spermatozoa counts, mucus gland weights and seminal vesicle weights, flying drones returning to Africanized or European colonies during afternoon mating periods were collected. Only Africanized colonies producing exclusively black drones and only European colonies producing exclusively yellow drones were used. Only drones typical of each colony were collected. Collected drones were stored in cages placed in colonies managed as queen-storage units. For measurements, their reproductive tracts were removed by dissection.

For each drone, a single seminal vesicle was macerated in a known volume of $0.9 \%$ saline solution. Estimates of total spermatozoa were made using a haemocytometer and a light microscope equipped with phase-optics.

The remaining seminal vesicle and both mucus glands were placed in separate clean dry vials equipped with air-tight seals. These vials were frozen and transported to Baton Rouge, Louisiana where the weights of their contents were determined.

\section{RESULTS}

Africanized drones weighed less and had fewer spermatozoa in their seminal vesicles than European drones (Table 1). In both cases the means were significantly different $(\mathrm{P}<0.0001)$ although their ranges overlapped. 
TABL. 1. - Means, standard errors of the means, and t-tests for weights, spermatozoa counts, mucus gland weights, and seminal vesicle weights of Africanized and European drones

\begin{tabular}{|c|c|c|c|c|}
\hline & $\begin{array}{c}\text { Weight (mg) } \\
X \pm S E(N)(1)\end{array}$ & $\begin{array}{c}\text { Spermatozoa } \\
\text { counts }(\times 106) \\
X \pm S E(N)(2)\end{array}$ & $\begin{array}{c}\text { Mucus gland } \\
\text { weights (mg) } \\
X \pm \text { SE (N) (3) }\end{array}$ & $\begin{array}{c}\text { Seminal vesicle } \\
\text { weights (mg) } \\
X \pm S E(N)(3)\end{array}$ \\
\hline $\begin{array}{l}\text { Drones } \\
\quad \text { Africanized } \\
\text { European }\end{array}$ & $\begin{array}{l}194.6 \pm 3.5(34) \\
220.2 \pm 5.3(25)\end{array}$ & $\begin{array}{l}4.6 \pm 0.9(81) \\
5.7 \pm 0.9(80)\end{array}$ & $\begin{array}{l}14.4 \pm 0.2(81) \\
14.2 \pm 0.2(86)\end{array}$ & $\begin{array}{l}1.5 \pm 0.08 \\
1.6 \pm 0.05\end{array}$ \\
\hline $\begin{array}{l}\text { Analyses } \\
\text { t-value } \\
\text { probability }\end{array}$ & $\begin{array}{l}4.52 \\
0.0001\end{array}$ & $\begin{array}{l}7.77 \\
0.0001\end{array}$ & $\begin{array}{l}0.71 \\
\mathrm{NS}\end{array}$ & $\begin{array}{c}0.77 \\
\text { NS }\end{array}$ \\
\hline
\end{tabular}

(1) Based on the weights of groups of minimally 8 and usually 10 drones per colony. $\mathrm{N}=$ number of colonies.

(2) Counts are for single seminal vesicles for individual drones collected in approximately equal numbers from 22 colonies of Africanized bees and 22 colonies of European bees.

(3) Weights are for both mucus glands and single seminal vesicles for individual drones collected as described above.

The weight of the seminal vesicles of Africanized drones were not significantly different from those of European drones (Table 1). The weight of mucus glands of Africanized drones were not significantly different from those of European drones (Table 1).

\section{DISCUSSION}

Various studies (reviewed by KoENIGER, 1985) have shown that queens mate with from 7-17 drones. Yet, the final numbers of spermatozoa retained in the spermathecae of naturally mated queens average $5.7 \times 10^{6}$ (MACKENSEN, 1955). Thus, queens void the majority of spermatozoa they receive from each drone. Despite having reduced numbers of spermatozoa, individual Africanized drones still produce more spermatozoa than a queen will retain from all her matings.

Because of this, the consequences of reduced spermatozoa counts for Africanized drones are difficult to predict. Three possibilities exist. First, reduced numbers of spermatozoa produced may lead to reduced numbers of spermatozoa reaching the spermatheca. As a correlated condition, Africanized queens may retain fewer spermatozoa in their spermathecae than European queens, thereby mating with an effective number of drones less than that mated by European queens. Second, reduced numbers of spermatozoa produced may be balanced 
by a greater proportion of the spermatozoa being retained by queens. This would give equivalent effective matings by both types of queens. Thirdly, Africanized queens may mate with more drones. Each of these possibilities is a hypothesis which can be tested with further experiments.

The reduced weight of Africanized drones possibly results from more economic feeding of drone larvae by Africanized nurse bees. Both European and Africanized worker larvae nursed by Africanized nurse bees weigh less than when they are nursed by European bees (RINDERER, et al., 1985 b).

It is interesting that the mucus glands of Africanized drones are equal in weight to those of European drones even though the total weight of Africanized drones is less. The precise role of mucus in natural mating is unclear. It does become involved in the formation of a «mating sign» (KoENIGER, 1985) and may be involved in competition among drones for greater representation of their spermatozoa in the final contents of queen's spermatheca. Certainly, drones show variation in the numbers of their spermatozoa which reach the spermatheca (MoriTZ, 1983). If mucus enhances deposition of spermatozoa in the spermatheca, Africanized drones could be equally competitive with European drones in spite of their smaller numbers of spermatozoa.

Received for publication in June 1985. Accepted for publication in August 1985.

\title{
ACKNOWLEDGEMENTS
}

This research was done in cooperation with the Louisiana Agricultural Experiment Station and Universidad de Centro Occidental, Lizandro Alvarado, Barquisimeto, Venezuela.

\author{
RESUME \\ COMPARAISON DE MALES AFRICANISES ET DE MALES EUROPEENS \\ (APIS MELLIFICA L.) : POIDS CORPOREL, POIDS DES GLANDES A MUCUS \\ ET DES VESICULES SEMINALES ET NOMBRE DE SPERMATOZOÏDES
}

On a prélevé au Venezuela dans 34 colonies d'abeilles africanisées et 25 colonies d'abeilles européennes de jeunes mâles adultes, récemment éclos. On a pesé des groupes d'au moins 8 et généralement 10 mâles par ruche. Les mâles africanisés sont significativement plus légers que les mâles européens : 195 et $220 \mathrm{mg}$ respectivement (Tabl. 1).

Un second prélèvement a été effectué sur des mâles rentrant à la ruche au cours de la période d'accouplement, dans 22 colonies européennes et 22 colonies africanisées. Les conditions expérimentales ont été choisies pour que les mâles européens soient exclusivement jaunes et les mâles mâles africanisés exclusivement noirs. Ces mâles ont été disséqués. On a dénombré les spermatozoïdes d'une vésicule séminale et pesé séparément l'autre vésicule et les deux glandes à mucus. 
Les mâles africanisés produisent significativement moins de spermatozoüdes par vésicule séminale que les mâles européens : 4,6 $\times 10^{6}$ et 5,7 $\times 10^{6}$ respectivement (Tabl. 1). Les vésicules séminales et les glandes à mucus des mâles européens et celles des mâles africanisés ne présentent pas de différence significative de poids.

\section{ZUSAMMENFASSUNG}

\section{EIN VERGLEICH AFRIKANISIERTER UND EUROPAISCHER DROHNEN : KÖRPERGEWICHT, GEWICHT VON SCHLEIMDRUSEN UND SAMENBLASCHEN, ZAHL DER SPERMATOZOEN}

Frischgeschlüpfte adulte Drohnen wurden von afrikanisierten und von europäischen Bienenvölkern in Venezuela gesammelt. Sie wurden in Gruppen von mindestens 8, gewöhnlich aber 10 Drohnen pro Volk gewogen. Afrikanisierte Drohnen waren signifikant leichter als europäische (195 mg gegenüber $220 \mathrm{mg}$, Tab. 1).

Eine zweite Gruppe von Drohnen wurde bei ihrer Rückkehr vom Hochzeitsflug gesammelt (22 europäische und 22 afrikanisierte Völker). Um jeden Fehler durch Verflug auszuschließen, wurde der Versuch so angelegt, daß die europäischen Drohnen ausschließlich gelb und die afrikanisierten Drohnen schwarz waren. Diese Drohnen wurden präpariert.

Die Zahl der Spermatozoen in einem der Samenbläschen wurde bestimmt, das andere Samenbläschen und die beiden Schleimdrüsen wurden getrennt gewogen.

Afrikanisierte Drohnen erzeugten signifikant weniger Spermatozoen pro Samenbläschen als europäische Drohnen $\left(4,6 \times 10^{6}\right.$ gegenüber $5,7 \times 106$, Tab. 1). Die Gewichte der Samenbläschen und Schleimdrüsen von afrikanisierten und europäischen Drohnen zeigten keine signifikanten Unterschiede.

\section{REFERENCES}

Daly H.V., Hoelmer K., 1985. - Rapid identification of Africanized honeybees by morphometric analysis (in preparation).

Dietz A., 1979. - An anatomical character suitable for separating drone honey bees of Apis mellifera ligustica from Apis mellifera adansonii. Proc. Apimondia Sym. Apic. in Hot Climates (Florianopolis), 102-106.

KeRR W.E., Bueno D., 1970. - Natural crossing between Apis mellifera adansonii and Apis mellifera ligustica. Evolution, 24, 145-148.

Koeniger G., 1985. - Reproduction and mating behavior. In : Rinderer, Bee Genetics and Breeding, Academic Press, NY. NY. (in press).

Mackensen O., 1955. - Experiments in the technique of artificial insemination of queen bees. J. Econ. Entomol., 48, 418-421.

Michener C.D., 1975. - The Brazilian bee broblem. Annu. Rev. Entomol., 20, 399-419.

Moritz R.F.A., 1983. - Homogeneous mixing of honeybee semen by centrifugation. J. Apic. Res., 22, 249-255.

Rinderer T.E., Hellmich R.L. II., DanKa R.G., Collins A.M., 1985 a. - Male reproductive parasitism : A factor in the Africanization of European honey-bee populations. Science, 228, 1119-1121.

Rinderer T.E., Sylvester H.A., Collins A.M., Pesante D., 1985 b. - Effect of nurse-bee genotype and comb size on morphometrically based identification of Africanized and European honey bees. Bulletin Entomol. Soc. Amer. (In Press). 